\title{
Potential Biodeteriogens of Indoor and Outdoor Surfaces (Coated With Gloss, Emulsion and Textcoat Paints)
}

\author{
L. O. Odokuma, D. P. Berebon* and C.B. Ogbonna \\ Department of Microbiology, Faculty of Biological Science, College of Natural and Applied Sciences, University \\ of Port Harcourt. P.M.B 5323 Port Harcourt Nigeria ${ }^{*}$
}

\begin{abstract}
Potential Biodeteriogens of indoor and outdoor surfaces (coated with gloss, emulsion and text coat paints) within the University of Port Harcourt, Nigeria were investigated. Potential Biodeteriogens implicated in deterioration of painted surfaces were bacteria, fungi, microalgae and cyanobacteria. The total heterotrophic bacteria counts and total fungal counts for outdoor and indoor painted surfaces ranged from $2.8 \times 10^{6}$ to $9.00 x$ $10^{6} \mathrm{cfu} / \mathrm{g}$ paint scrape, $1.56 \times 10^{4}$ to $6.6 \times 10^{4} \mathrm{cfu} / \mathrm{g}$ paint scrape; and $1.1 \times 10^{6}$ to $6.5 \times 10^{6} \mathrm{cfu} / \mathrm{g}$ paint scrapes, $1.31 \times 10^{4}$ to $9.8 \times 10^{4} \mathrm{cfu} / \mathrm{g}$ paint scrapes respectively. The result of THB and TF count expressed graphically showed surfaces with increasing order of microbial load: Gloss paints < Text coat paint < Emulsion paints. Predominant bacterial genera isolated from the surfaces include Bacillus (29.0\%), Pseudomonas (22.6\%), Proteus (19.4\%), Serratia (16.1\%), Citrobacter (6.5\%), Enterobacter (3.2\%) and Klebsiella (3.2\%). Fungal genera isolated include: Alternaria, Aspergillus, Cladosporium, Fusarium,Geotrichum, Gleosporium, Penicillum, Rhizopus, Saccharomyces and Stachybotrys. Fungi were the predominant biodeteriogens. Predominant microalgae isolated from the wet painted surfaces include Chorella, Characium, Closterium, Geminella, Oscillatoria, Totrogonnidium and Triceratium . Physicochemistry of various paint surfaces revealed the following: TOC $(1.30-3.49 \%)$, Phosphate $(0.39-8.82 \mathrm{mg} / 100 \mathrm{~g})$, nitrate $(4.64-187.58 \mathrm{mg} / 100 \mathrm{~g})$, sulphate (99.78-285.00mg/100g), pH (8.55-9.59), oil and Grease (125.00-285.00mg/100g).Result showed that different consortia of biodeteriogens implicated in indoor and outdoor painted surfaces are dependent on the chemical compositions of the various paints, nature of the coating surfaces and physicochemical parameters influencing the microbial processes. Emulsion surfaces habour most potential biodeteriogens on their surfaces than the other surfaces. There were significant differences $(P<0.05)$ in the various potential biodeteriogens, categories of painted surfaces, indoor and outdoor surfaces.
\end{abstract}

Keywords: Biodeteriogens, indoor, outdoor, painted surfaces

\section{Introduction}

Paints are stable mechanical mixtures of one or more pigments (Sharma, 2006) and of various chemical components (Constantino, 1994). Paints are used as protective coatings to prevent the environmental weathering of materials and to provide a decorative finish. To achieve both of these desirable properties, the paint film must not be susceptible to microbial utilization. However, paints are susceptible to deterioration by biodeteriogens. It is impossible to maintain painted surfaces in a sterile condition and free of exposure to organisms spores (Hare, 1998). The three main classes of biodeteriogens that can colonize paints are fungi, algae, bacteria (Gaylarde, 2005), others are lichens (Stefanie et al., 2009). Microorganisms have the potentials to grow in liquid paint prior to application and also on paint films after application. Paint manufacturers may use biocides in their formulations to prevent these organisms developing.

Biocides are chemical products containing one or more active substances which control or inhibit the growth of microorganism in the paint without having undesirable effect on other properties of the paint. However, biocide alone usually will not solve a microbiological problem (Woods et al., 1982). Biocides have properties ranging from anti-fungal, anti-algal to anti-bacterial.

A major challenge in the management of biodeterioration is the control of microbial growth in paint. Paint may be broadly categorized as solvent-borne products (e.g. Gloss paint) and water-borne coating (e.g. emulsion paint and text coat paints). While solvent- borne products are not prone to in - can attack, water-borne coatings are prone to in-can attack by both bacteria and fungi because all microorganisms need both water and nutrients and some, like algae, also need sunlight.

Growth of microorganisms on paintings may cause aesthetic and structural damage (Orio, 1999). Aesthetic damage involves pigment discoloration, stains, and formation of biofilm on the painted surface, paint layers, formation of paint blisters, and degradation of support polymers or of glues and binders resulting in detachment of the paint layer from the support (Orio, 1999; Stefenie et al., 2009).

The rate of microbial colonization and the challenges in the microbial population is a function of the substrate composition and environmental conditions (humility, temperature, light and probably pH etc.) (Orio, 1999). The aim of this study is to identify the biodeteriogens associated with the deterioration of painted 
surfaces. Also the various physicochemical parameters enhancing such deterioration will also be considered. In the present study, potential biodeteriogens of indoor and outdoor surfaces (coated with gloss, emulsion and textcoat paints) and various physicochemistry of various paint surfaces were studied.

\section{Study area and Source of samples}

\section{Materials And Methods}

Various paint scrapings used for this study were collected from the University of Port Harcourt- main Campus in Port Harcourt. Eighteen (18) paint scrapes were obtained from emulsion, gloss and text-coated surfaces. Emulsion scrapes were generated from students Hostels (Nelson Mandela) A, B, C, and D, Gloss scrapes from the University Convocation Arena while Text-coat scrapes from English House (Department of English).

\section{Sample collection and preparation}

Paint scrapes were collected aseptically by scraping the surface of the walls into a sterile bottle. The samples were labeled as follows; $\mathrm{E}_{1}, \mathrm{E}_{2}, \mathrm{E}_{3}, \mathrm{e}_{4}, \mathrm{e}_{5}, \mathrm{e}_{6}, \mathrm{G}_{7}, \mathrm{G}_{8}, \mathrm{G}_{9}, \mathrm{~g}_{10}, \mathrm{~g}_{11}, \mathrm{~g}_{12}, \mathrm{~T}_{13}, \mathrm{~T}_{14}, \mathrm{~T}_{15}, \mathrm{t}_{16}, \mathrm{t}_{17}$ and $\mathrm{t}_{18}$; with $\mathrm{E}$, $\mathrm{G}$ and $\mathrm{T}$ symbolizing outdoor emulsion, gloss and Text-coat paints. The lower cases; $\mathrm{e}, \mathrm{g}$ and $\mathrm{t}$ symbolize indoor-emulsion, gloss and text-coat paints respectively. The samples were analysed immediately.

\section{Microbiology of the scraping \\ Enumeration of total heterotrophic bacteria and fungi counts}

Spread plate technique was adopted according to APHA (1998). Ten fold serial dilutions were done. One gram of the paint scrapings was weighed out from each samples and dispensed into the three test tubes containing normal saline. Each tube was shaken for thorough mixing of the mixture. One (1ml) was pipette into another test tube containing $9 \mathrm{mls}$ normal saline to give a $10^{-1}$ dilution. The sample was diluted serially up to $10^{-6}$. The same procedure was followed for other samples. The test tubes were covered with cotton wool. Exactly $0.1 \mathrm{ml}$ aliquots of the dilutions was spread inoculated into Petri dishes containing Nutrients agar (Oxoid) and Potato dextrose agar (PDA, Antech) for total culturable bacteria and total culturable fungi enumeration respectively ( Chikere et al., 2009; Ibiene et al., 2011). Enumeration of colonies was done through the formula: No of colonies x dilution factor

Volume plated

\section{Isolate purification}

The colonies formed on Nutrient agar for bacteria were further purified by sub-culturing on nutrient agar and the identification of the bacteria followed the scheme of J. G. Holt (1994).

Isolates on PDA were sub-cultured on nutrient agar containing antibiotics (penicillin G, $0.05 \mathrm{~g} / \mathrm{l}$; chloramphenicol, $0.5 \mathrm{~g} / \mathrm{l}$ and streptomycin, $0.025 \mathrm{~g} / \mathrm{l}$ ) to suppress bacterial growth. All plates were incubated at $30+2^{0} \mathrm{C}$ for $72 \mathrm{~h}$. pure fungi isolates were further studied using lacto phenol stain. A small portion of the fungal growth was picked with a wire loop and placed on clean and grease free slide. A drop of lacto phenol was added and the preparation was covered with cover slip. The slide was observed under x10 and x40 objective lenses (Obire et al., 2008).

\section{Physicochemical parameters of the paint scraping}

Total organic carbon (TOC) was determined using dichromate method according to APHA, 1998. The pH was determined using PYE UNICAM PW 9418 pH and reference electrode (APHA, 1998). Phosphate and sulphate were determined using ascorbic acid method and Turbidometric methods (APHA), 1998 respectively.

Nitrate was estimated using Brucine method according to APHA, 1998). Oil and grease was determined by spectrophotometer.

\section{Isolation of Microalgae}

The method of Michael and Hirsch (1999) was employed. About 10 gram of algal scrapes was added to $100 \mathrm{ml}$ of sterile normal saline. The solution was homogenized for thorough mixing of the mixture and filtered through a sterile filter paper (Whatman No 1) into $500 \mathrm{ml}$ Erlenmeyer flasks containing $300 \mathrm{ml}$ sterile BG-11 media. The broth medium had in $\mathrm{g} / \mathrm{l}$ the following; $\mathrm{NaNO}_{3}, 15 \mathrm{~g} ; \mathrm{K}_{2} \mathrm{HPO}_{4} 3 \mathrm{H}_{2} \mathrm{O}, 0.04 \mathrm{~g} ; \mathrm{MgSO}_{4} .7 \mathrm{H}_{2} \mathrm{O}, 0.006 \mathrm{~g}$; ferric ammonium citrate, $0.006 \mathrm{~g}$; Ethylene diaminetetra acetic acid (EDTA). Disodium magnesium salt $0.001 \mathrm{~g}$; $\mathrm{Na}_{2} \mathrm{CO}_{3}, 0.02 \mathrm{~g}$. Trace metal Mix $\mathrm{A}_{5}, 1 \mathrm{ml}$; metal mix had $\mathrm{n} \mathrm{g} / \mathrm{l}$ the following; $\mathrm{H}_{3} \mathrm{BO}_{3}, 2.86 \mathrm{~g} ; \mathrm{MnCl}_{2} .4 \mathrm{H}_{2} \mathrm{O}, 1.81 \mathrm{~g}$; $\mathrm{ZnSO}_{4} .7 \mathrm{H}_{2} \mathrm{O}, 0.22 \mathrm{~g} ; \mathrm{CuSO}_{4} .5 \mathrm{H}_{2} \mathrm{O}, 0.08 \mathrm{~g} ; \mathrm{Na}_{2} \mathrm{MO} .2 \mathrm{H}_{2} \mathrm{O}, 0.39 \mathrm{~g} ; \mathrm{CO}\left(\mathrm{NO}_{3}\right)_{2} .6 \mathrm{H}_{2} \mathrm{O}, 0.04 \mathrm{~g}$. The broth culture was incubated under constant aeration using Charles Austin Pump TB 185, aerators and white light of $15 \mu$ EM ${ }^{2} S^{-2}$ for four weeks to bloom giving a green coloration at room temperature $\left(28 \pm 2{ }^{0} \mathrm{C}\right)$. After incubation, serial 
dilutions of the broth culture were plated out in triplicate on BG-11 agar medium supplemented with $100 \mu \mathrm{g} / \mathrm{ml}$ nystatin and $100 \mu \mathrm{g} / \mathrm{ml}$ of chloramphenicol (Odokuma and Smith, 2007).

\section{Purification of microalgae colonies}

Discrete colonies on BG-11 agar medium were picked and transferred into 100ml of sterile BG-11 medium in a $250 \mathrm{ml}$ Erlenmeyer flask. The cultures were incubated for four weeks in order to obtain sufficient algal biomass. Using a sterile $1 \mathrm{ml}$ pipette, $0.1 \mathrm{ml}$ of the $10^{-6}$ dilution of the broth culture was plated onto BG-11 agar fortified with nystatin and chloramphenicol antibiotics by spread plate technique. The plates were incubated for four weeks and observed at weekly intervals for growth. Microscopic examination using the light microscope was made to determine colonies that showed characteristics of various algae (Round, 1973; Elenwo and Nwachukwu, 2005; Dutta, 2007). Discrete colonies were picked and transferred into BG-11 broth and incubated at room temperature $\left(28 \pm 2^{\circ} \mathrm{C}\right)$ under previously discussed conditions for four weeks to bloom. The cultures were judged axenic when there was no growth of heterotrophic bacteria after four weeks. They were also taken as stock cultures (Odokuma and Smith, 2007).

\section{Results}

The results of the Percentage occurrence of bacterial isolates are shown in Table 1 and Figure 3. Amongst the bacterial isolated include; Bacillus sp. (29.0\%), Pseudomonas sp. (22.6\%) and Serratia sp. (16.1\%). Bacillus $s p$ had the highest frequency (29.0\%) followed by Pseudomonas sp, Proteus $s p$, Serratia $s p$. and Citrobacter sp. while Enterobacter sp. and Serratia sp. had the lowest frequency.

\begin{tabular}{lcc}
\hline Biodeteriogens & Occurrence/gram of paint scrapes & Percentage (\%) \\
\hline & 9.0 & 29.0 \\
Bacillus sp & 7.0 & 22.6 \\
Pseudomonas sp & 6.0 & 19.4 \\
Proteus sp & 5.0 & 16.1 \\
Serratia sp & 2.0 & 6.5 \\
Citrobacter sp & 1.0 & 3.2 \\
Enterobacter sp & 1.0 & 3.2 \\
Klebsiella sp & & \\
& & \\
\hline & 31 & 100 \\
\hline
\end{tabular}

The probable bacteria genera isolated from the deteriorated indoor and outdoor painted surfaces included the following: Bacillus sp, Pseudomonas sp, Proteus sp, Serratia sp, Citrobacter sp, Enterobacter $s p$ and Klebsiella $s p$. while fungi isolates include: Aspergillus sp, Alternaria sp, Fusarium sp, Cladosporium sp, Penicillium sp, Gleosporium sp, Rhizopus sp, Stachybotry sp, Saccharomyces sp and Geotricum sp. as shown in Table 2.

Table 2: Fungal deteriogens from indoor and outdoor paint scrapes

\begin{tabular}{lc} 
Indoor paint scrapes & Outdoor paint scrapes \\
\cline { 2 - 2 } Gleosporium $s p(1)$ & Alternaria $s p(1)$ \\
Saccharomyces $s p(1)$ & Geotrichum $s p(1)$ \\
Penicillum $s p(1)$ & Rhizopus $s p(1)$ \\
Aspergillus $s p . \quad(3)$ & Penicillum $s p(1)$ \\
Cladosporium $s p(2)$ & Fusarium $s p(1)$ \\
Stachybotrys $s p(2)$ & Aspergilus $s p(2)$ \\
Fusarium $s p(2)$ & *Numbers in parenthesis represent the number of species isolated
\end{tabular}

The probable microalgae and cyanobacteria isolated from deteriorated wet surfaces (table 3) include; Oscillatoria sp, Chlorella $s p$, Characium $s p$, Closterium $s p$, Geminella $s p$, Totrogonidium $s p$, and Triceratium $s p$. 
Table 3: Identification of various microalgae from Painted wet surfaces

\begin{tabular}{ll}
\cline { 2 - 2 } Isolates & Probable Genera \\
E1 & Oscillatoria $s p$ \\
E2 & Closterium $s p$ \\
G3 & Chlorella $s p$ \\
G4 & Geminellia $s p$ \\
G5 & Characium $s p$ \\
T6 & Totrogonidium $s p$ \\
& \\
T7 & Triceratium $s p$ \\
\hline
\end{tabular}

The THB count ranged from $2.83 \times 10^{6}$ to $9.00 \times 10^{6} \mathrm{cfu} / \mathrm{g}$ for outdoor painted surfaces. Again, for indoor painted surfaces, the THB ranged from $1.12 \times 10^{6}$ to $6.50 \times 10^{6} \mathrm{cfu} / \mathrm{g}$ (Table 4a,b) while total fungi count ranged from $1.56 \times 10^{4}$ to $6.60 \times 10^{4}$ and $1.31 \times 10^{4}$ to $9.82 \times 10^{4}$ for outdoor and indoor respectively( table $\left.4 \mathrm{a}, \mathrm{b}\right)$. The rates of deterioration among the THB and TF for indoor and outdoor surfaces are shown in Figure 1 and 2 respectively.

The THB and TF can be used to determine the rate of deterioration among the various painted surfaces. The cumulative physiochemical parameters of phosphate, nitrate, sulphate, TOC, oil and grease and $\mathrm{pH}$ for emulsion, text coat and gloss paints are shown in Table 5.

The $\mathrm{pH}$ maintained an alkaline concentration for all the paint types. The TOC shows the highest value for gloss paint and least value for Emulsion paint. The nitrate, sulphate, oil and grease shows a fairly high concentration for all paint scrapes. However, the phosphate concentration remains fairly low for all paint scrapes analyzed.

Table 4: Total heterotrophic bacterial (THB) and Total fungal (TF) count from paint scrapings Table 4a: THB and TF for outdoor surfaces

\begin{tabular}{llcc}
\hline Paint scraped type & Surface category & THB $\left(\times 10^{6} \mathrm{cfu} / \mathrm{g}\right)$ & TF $\left(\times 10^{4} \mathrm{cfu} / \mathrm{g}\right)$ \\
\hline E1 & Outdoor & 9.00 & 6.40 \\
E2 & Outdoor & 8.00 & 5.70 \\
E3 & Outdoor & 6.70 & 3.20 \\
G1 & Outdoor & 3.40 & 1.58 \\
G2 & Outdoor & 2.99 & 1.56 \\
G3 & Outdoor & 2.83 & 2.92 \\
T1 & Outdoor & 6.42 & 2.30 \\
T2 & Outdoor & 7.40 & 3.09 \\
T3 & Outdoor & 6.60 & 1.92 \\
\hline
\end{tabular}

Legend: $\mathrm{E}=$ Outdoor Emulsion; $\mathrm{G}=$ Outdoor Gloss; $\mathrm{T}=$ Outdoor text-coat

Table 4b: THB and TF for Indoor Surfaces

\begin{tabular}{|c|c|c|c|}
\hline Paint type & Surface category & THB $\left(10^{6} \mathrm{cfu} / \mathrm{g}\right)$ & TF $\left(\times 10^{4} \mathrm{cfu} / \mathrm{g}\right)$ \\
\hline e1 & Indoor surfaces & 5.84 & 9.82 \\
\hline $\mathrm{e} 2$ & Indoor surfaces & 3.73 & 8.14 \\
\hline $\mathrm{e} 3$ & Indoor surfaces & 6.50 & 7.90 \\
\hline g1 & Indoor surfaces & 3.10 & 3.87 \\
\hline g2 & Indoor surfaces & 2.55 & 2.00 \\
\hline g3 & Indoor surfaces & 1.12 & 1.31 \\
\hline $\mathrm{t} 1$ & Indoor surfaces & 3.52 & 4.25 \\
\hline $\mathrm{t} 2$ & Indoor surfaces & 3.28 & 5.22 \\
\hline $\mathrm{t} 3$ & Indoor surfaces & 5.53 & 5.55 \\
\hline
\end{tabular}

Legend: $\mathrm{e}=$ Indoor Emulsion; $\mathrm{g}$ = Indoor gloss; $\mathrm{t}=$ Indoor text-coat 
Table 6: Cumulative Average for Physiochemical parameters of the various painted Surfaces at Abuja Campus, University of Port Harcourt, Nigeria Parameters Surface paint types

\begin{tabular}{|c|c|c|c|c|c|c|}
\hline & $\mathbf{E}$ & $\overline{\mathbf{e}}$ & $\mathbf{G}$ & $\mathbf{g}$ & $\mathbf{T}$ & \\
\hline Total Organic & & & & & & \\
\hline Carbon (\%) & 1.30 & 2.53 & 3.49 & 1.26 & 1.44 & 1.90 \\
\hline $\begin{array}{l}\text { Phossphate } \\
\text { (mg/100g) }\end{array}$ & 6.81 & 4.11 & 0.39 & 8.82 & 3.94 & 5.02 \\
\hline $\begin{array}{l}\text { Nitrate } \\
(\mathrm{mg} / 100 \mathrm{~g})\end{array}$ & 187.58 & 97.09 & 4.64 & 75.46 & 61.45 & 136.79 \\
\hline $\begin{array}{l}\text { Sulphate } \\
(\mathrm{mg} / 100 \mathrm{~g})\end{array}$ & 101.69 & 141.05 & 120.41 & 99.78 & 118.69 & 285.00 \\
\hline $\begin{array}{l}\text { Oil and Grease } \\
(\mathrm{mg} / 100 \mathrm{~g}) \\
\mathrm{pH}\end{array}$ & $\begin{array}{r}150.00 \\
8.76\end{array}$ & $\begin{array}{c}170.00 \\
9.59\end{array}$ & $\begin{array}{c}200.00 \\
9.20\end{array}$ & $\begin{array}{c}135.00 \\
9.30\end{array}$ & $\begin{array}{c}125.00 \\
8.55\end{array}$ & $\begin{array}{c}285.00 \\
9.16\end{array}$ \\
\hline
\end{tabular}

Legend: $\mathrm{E}$ = Cumulative Outdoor Emulsion average; e = Cumulative Indoor Emulsion average; $\mathrm{G}=$ Cumulative Outdoor Gloss average; $\mathrm{g}=$ Cumulative Indoor Gloss average; $\mathrm{T}=$ Cumulative Outdoor text-coat average; $\mathrm{t}=$ Cumulative Indoor text-coat average

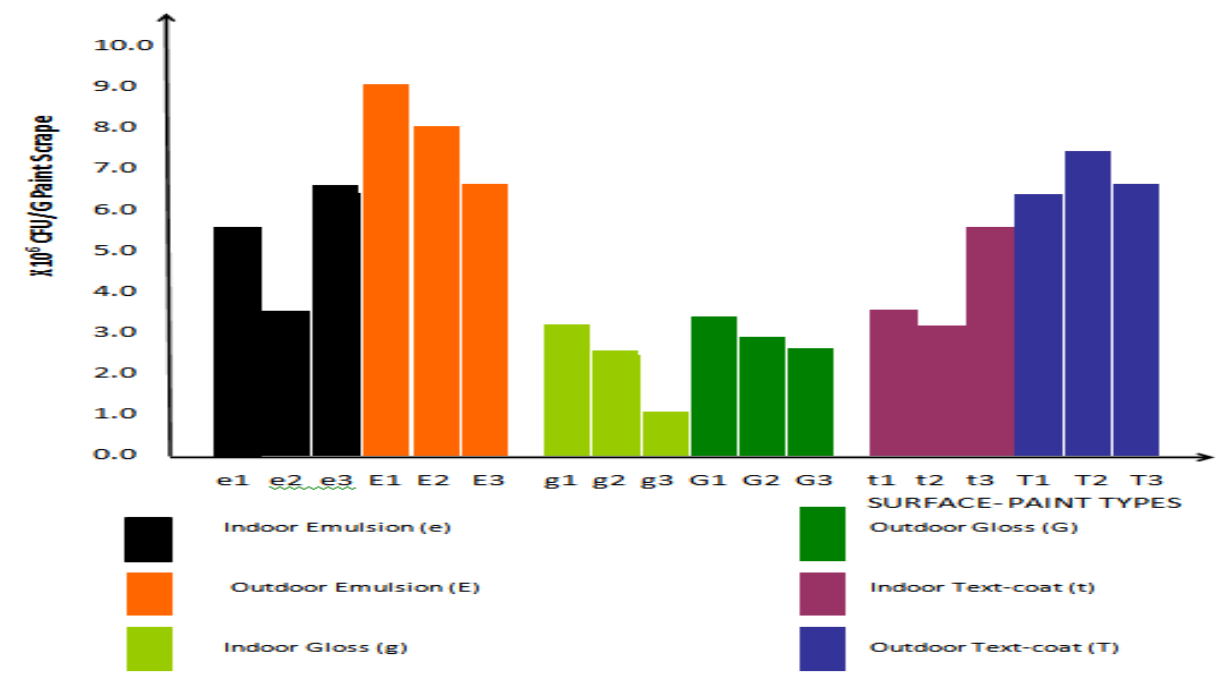

Figure 1: Estimation of microbial numbers on Indoor and outdoor surfaces with different coatings (Emulsion, Text-coat and Gloss paints) 

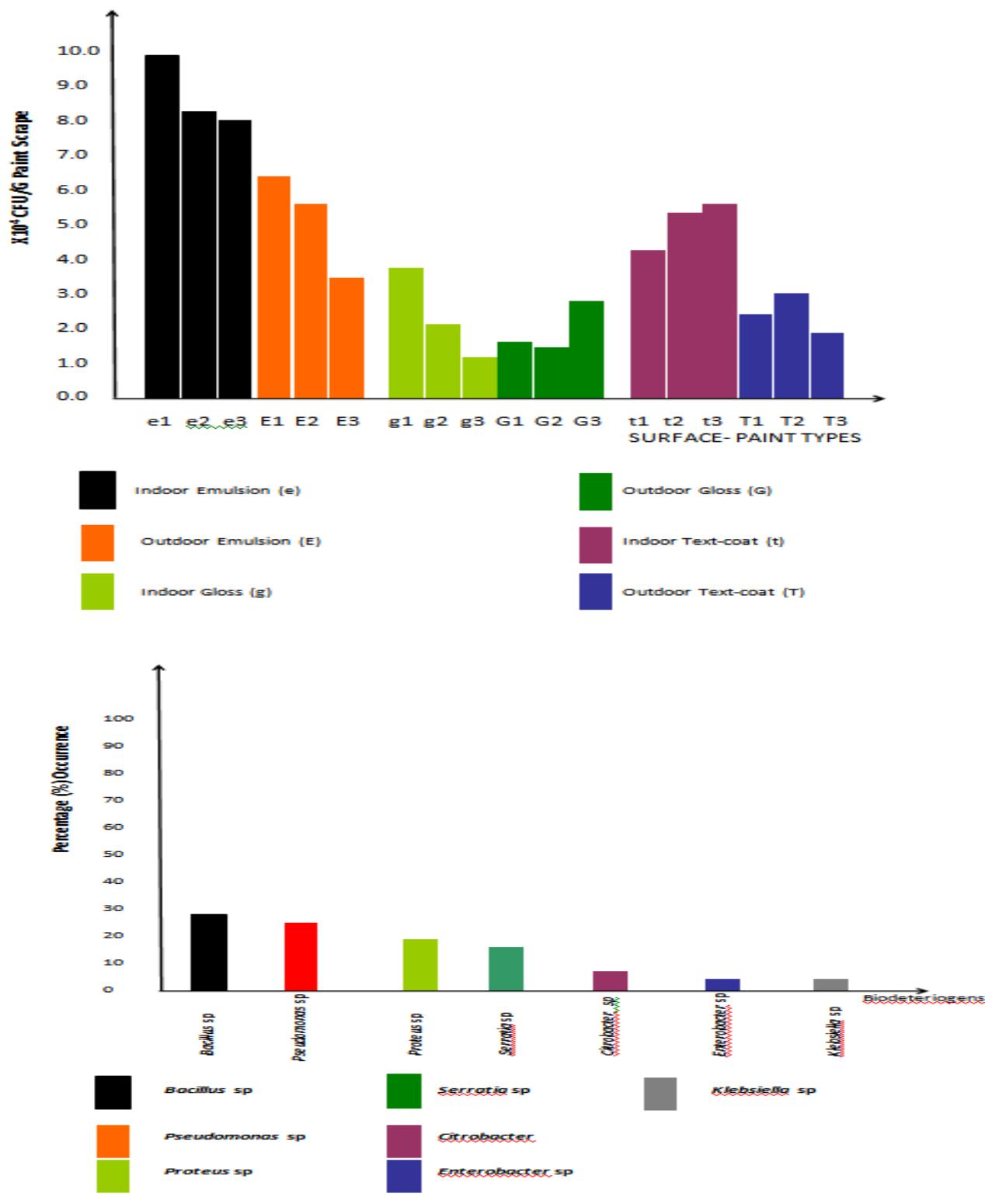

\section{Discussion}

Biodeteriogens of painted surfaces are consortia of microorganisms which cause deterioration while utilizing the paint or painted surfaces as a substrate - source of carbon and energy. The results indicated that bacteria, fungi and algae are the potential biodeteriogens of painted surfaces. This has shown that the same type of painted surface undergoes varying microbial levels depending on whether they are indoor or outdoor due to their exposure to environmental factors. A total of thirty one (31) bacteria isolates (table 2) belonging to seven (7) genera were isolated from deteriorated indoor and outdoor painted surfaces coated with emulsion, text - coat and Gloss paints. This research study was performed during the rainy season (June - August). The results shows the preponderance of Bacillus sp (29.0\%) over Pseudomonas sp. (22.6\%), Proteus sp.(19.4\%) and Serratia sp (16.1\%) followed by Citrobacter sp. (6.5\%), Enterobacter sp. (3.2\%) and Klebsiella sp.(3.2\%). This is partly in accordance with the view of Okpokwasili and Ituen (1995).They observed that Bacillus $s p$ was most frequently isolated but Pseudomonas $s p$ and Proteus $s p$ were the least encountered. However this study has shown that Bacillus sp and Pseudomonas sp exhibited the highest preponderance on painted surfaces. This may be attributed to the survival strategies evolved by each organism (Atlas and Bartha, 1988).

Statistical analysis using student $t-$ test has shown a significant difference $(P<0.05)$ for both indoor and outdoor surfaces as well as the various types of paints (emulsion, text coat and gloss paints).

Fungi and bacteria populations also shows a significant difference $(\mathrm{P}<0.05)$ for both indoor and outdoor deteriorated painted surfaces. A total of fifteen (20) fungi isolates belonging to ten (10) genera were identified. Aspergillus exhibited a maximum microbial population. Aspergillus sp, Cladosporium sp, Fusarium $s p$ and Stachybotrys $s p$ show preponderance among indoor isolates. Perhaps these accounts for the "Sick 
building syndrome" associated with indoor air contaminated with their spores (Jawetz et al., 2007; Prescott et al., 2008; Talaro, 2008). The results of the total fungi count revealed that there is no significant difference between outdoor population of fungi and and indoor population.

Externally, the problems are greater in the tropics where fungi cause defacement of painted surfaces (Allsopp et al., 2004) with restricted rapid surface drying. Typically, indoor surfaces which support heaviest fungal growth include Bathroom, Basements, Garages and Kitchens. Among the algal deteriogens, Chollera sp. and Oscillatoria $s p$ were widely observed and isolated from all painted scrapings.This was also reported by Okpokwasili and Ituen (1995).

Unlike bacteria and fungi, indoor painted surfaces not exposed to light shows no algae bloom when cultured. Similarly, microalgae and bloom were observed in outdoor paintings when cultured for four weeks. It may therefore be suggested that algae require a source of light to grow whether on deteriorated surfaces or in culture broth. Thus, algae cannot cause in-can deterioration of paints due to its photosynthetic nature.

The phosphate, nitrate and sulphate concentrations for the indoor and outdoor painted surfaces exhibited varying different phosphate level at the lowest concentration. The microbes make use of the nitrate and phosphate in the degradation process (Ebuehi et al., 2005) and they are limiting nutrients for microbial growth (Odokuma and Smith, 2007). It may be suggested therefore that phosphorus is the limiting nutrient in our study in accordance to Liebig's Law of minimum (Prescott et al., 2008; Atlas and Bartha, 1998) as its availability determine the total biomass of the various biodeteriogens.

Microorganisms require sulphate, phosphate, and nitrate for their various anabolic and catabolic processes. The microbial utilization of these substrate resulted in the microbial population and diversity observed for the various painted surfaces.

Most microalgae can utilize the oil and grease component of the paint formulations.Obire and Anyanwu (2009) observed that some fungi utilized oil in treated soil samples while others were not oil utilizers. The reduced presence of oil and grease favours the growth of species that could utilize alternative carbon sources (Okpokwasili and Odokuma, 1990). According to Okpokwasili and Odokuma, (1990) the pH appears to be lower in dry season and relatively higher in the rainy season due to dilution effect. The $\mathrm{pH}$ of the various categories of painted surfaces was high indicative of alkaline concentration. Many bacteria and fungi tolerate alkaline $\mathrm{pH}$ up to 9.0 but have optima near neutrality while some cyanobacteria are alkalophilic (Atlas and Bartha, 1998).

The total heterotrophic bacteria (THB) and total fungal counts (TFC) were consistent with our physicochemical parameters. The discrepancies observed in the THB and TF (Table 5a, b) results may be attributed to tolerance of each biodeteriogen to various environmental determinants (conditions) and physicochemical parameters of the paint and painted surfaces. The result of THB and TF counts (cfu/g) in the current research study show the rate of deterioration per unit gram of paint-type analyzed. It is therefore coterminous with the rate of deterioration as the number of biodeteriogens per unit gram of paint scrape is directly proportional to the magnitude of deterioration caused to such painted surfaces.

Provided other physicochemical parameters are within tolerance limits. The representation of THB and TF counts (fig 1 and 2) in multiple bar charts showed a modal value for Emulsion paints followed by text-coat paints and lastly, Gloss paints. This implied that the increasing order of deterioration is Gloss paints $<$ Text-coat $<$ Emulsion paints.

This study has shown that fungal deterioration of painted surfaces may be attributed among others to their tolerance to $\mathrm{pH}$, oil and grease; production of resistant spores to less favorable physicochemical and environmental conditions. The bacteria deteriogens were more susceptible to the physicochemical and environmental conditions. The prevalence of Bacillus, Pseudomonas and Proteus may be attributed to their tolerance to high $\mathrm{pH}$ concentrations, oil and grease as well as biofilms formation potentials. However, Bacillus the only isolated Gram positive bacteria exhibited highest preponderance due to its versatile intrinsic deterioration potentials which may be attributed to its ability to produce protease and lipases that are stable at high temperature, at alkaline $\mathrm{pH}$ and in the presence of detergents (Atlas and Bartha, 1998) as well as production of spores which could resist less favorable physiochemical and environmental condition.

\section{Conclusion}

This study has demonstrated that biofouling of various painted surfaces within the University of Port Harcourt, Nigeria are due to potential biodeteriogens, especially painted surfaces which provide substrates for microorganisms. However environmental factors plays key role in the deterioration of painted surfaces. The various physico-chemical parameters influencing microbial growth on such surfaces were investigated. These potential biodeteriogens could aid paint manufacturers in production of effective biocides capable of protecting various paint formulations from microbial deterioration in Nigeria. This current study has shown that consortia of potential biodeteriogens are implicated in the deterioration of painted surfaces with an increasing order of deterioration as Gloss paints $<$ Text coat $<$ Emulsion paints. 


\section{References}

[1]. Atlas,R.M and Bartha, R.(1998).Microbial ecology:Fundamentals and Applications.4 ${ }^{\text {th }}$ edition.pp6,174,281 and 316 .

[2]. Allsopp D, Seal K. J. and C.C. Gaylarde 2004. Introduction to biodeterioration, $2^{\text {nd }}$ ed. Cambridge university press, pp. 50 177.

[3]. American Public Health Association (1998). Standard Method for the Examination of Water and Wastewater 19 ${ }^{\text {th }}$ edition Washington DC.

[4]. Chikere, C.B., G.C. Okpokwasili and B.O. Chikere. 2009. Bacterial diversity in a tropical crude oil-polluted soil undergoing bioremediation. Afri. J. Biotech. 8 (11): 2535-2540.

[5]. Constantino M. 1994. Painting Modern $20^{\text {th }}$ Century. Smithmark. New York. pp 176.

[6]. Dutta, A.C. 2007. Botany for Degree students. $6^{\text {th }}$ ed. Oxford University Press. pp: 341-395.

[7]. Elenwo, E.N and E.O. Nwachukwu. 2005. A textbook on seedless plants. Springfield publisher Ltd. Owerri, Nigeria.

[8]. Ebuehi, O.A.T., I.B. Abibo, P.D. Shhekwolo, K.J. Sigismund, A. Adoki, and I.C. Okoro, 2005. Remediation of crude oil contaminated soil by Enhanced Natural Attenuation technique. J. Appl. Sci. Environ. Manage. 9 (1): 103 - 106.

[9]. Gaylarde,C.C and Gaylarde,P.M.(2005).A comparative study of the major microbial biomass of biofilms on exteriors of buildings in Europe and Latin America.International Biodeterioration \&Biodegradation,55(2),131-139.

[10]. Hare,C.H(1998).Paint film degradation,mechanism and control.SSPC, architects memo.Online.

[11]. Holt, J. G. (Ed) 1994. The Bergey's Manual of Determinative Bacteriology ( $9^{\text {th }}$ ed.). Baltimore (The Williams and Wilkins Co).

[12]. Ibiene A.A., F.A. Orji, C.O. Ezidi and C.L. Ngwobia 2011. Bioremediation of hydrocarbon contaminated soil in the Niger Delta using spent mushroom compost and other organic wastes. Nig. J. Agric. Food Environ. 7(3): 1-7.

[13]. Jawetz, Melnick and Adelberg (eds). 2007. Medical Microbiology. $24^{\text {th }}$ ed. Mc Graw-Hill Companies, Inc. pp. 158 and 649.

[14]. Michael, J.F. and C.F. Hirsch .1991. Methods for isolation and purification of cyanobacteria. Appl. Environ. Microbiol. 57 (5): $1448-1452$.

[15]. Okpokwasili, G.C. and L.O. Odokuma. 1990. Effect of salinity on biodegradation of oil spill dispersants. Waste Management. 10: $141-146$

[16]. Okpokwasili, G.C. and Ituen,A.(1996).Fouling microflora of paintedsurface.Material and Organismen,30,155-159

[17]. Orio, C. 1999. Microbial Degradation of paintings. Appl. Environ. Microbiol. 65: 879 - 885.

[18]. Odokuma, L.O. and M.N. Ibor.( 2002). Nitrogen fixing bacteria enhanced bioremediation of crude oil pollution soil. Global J. Pure and Appl. Sci. 8(4): 453-468.

[19]. Odokuma, L.O. and V.A. Smith. 2007. Biodegradation of a Nigerian crude oil by a microalga and a cyanobacterium. Tropical Freshwater Biology. 16 (1): 17 - 18

[20]. Obire O. and E.C. Anyanwu. 2009. Impact of various concentrations of crude oil on fungal populations of soil. Int. J. Environ. Sci. Tech. 6(2): $211-218$

[21]. Prescott, Harley and Klein's Microbiology 2008. $7^{\text {th }}$ edition, Mc Graw-Hill Companies, Inc. pp. 123, 142-144, 653-655 and 710713.

[22]. Round, F.E. 1973. In Biology of the algae (ed). Edward Arnold. Cambridge University Press, New York.

[23]. Stefanie, S., O. Ortega - Morales and C. Gaylarde. 2009. Microbial Deterioration of stone monuments- An updated overview Advances in Appl. Microbiol. 66: 97-139.

[24]. Talaro, K.P. 2008. Foundations in Microbiology, $6^{\text {th }}$ ed. Mc Graw-Hill Companies, Inc. pp 139 and 806.

[25]. Woods, W.B., K. Blitz, L.B. Denpsey. 1982. Industrial biocides for use in coating.

[26]. Sharma, B.K. 2006. Industrial Chemistry (including chemical Engineering), $15^{\text {th }}$ ed. Manjula Sharma (editor). GOED Publishing House, Meerut. pp $1351-1360$. 